\title{
EARTHQUAKE INSURANCE
}

\author{
D.J. Scott
}

\section{INTRODUCTION}

This paper is about insuring buildings and contents against the risk of earthquake. There are problems encountered with the assessment and underwriting of the earthquake risk, and there are lessons to be learnt by insurers following the Edgecumbe and Mexico earthquakes. Discussing these matters will lead to conclusions and recommendations that:

(a) The exposure to the seismic risk must be properly assessed, costed, and spread more equitably amongst the community :

(b) All parties likely to be involved in an earthquake should establish closer relationships now to improve disaster planning to cope with a great earthquake.

\section{BACKGROUND}

\section{Insurance against Fortuities}

The main difference between Life Assurance and Fire and Casualty Insurance is that the former assures the policyholder of the payment of a predetermined sum of money if the policyholder survives to a maturity date, or in the event of death. Fire and Casualty Insurance of property may or may not result in the payment of monies, the amount of which is not necessarily predetermined and the insured peril or event may or may not occur. Life Assurance relates to assured events whilst Property Insurance relates to fortuities. It could be said that earthquake insurance is the exception which proves the rule for earthquakes will occur in New Zealand; it is just a question of when and where.

\section{Earthquake and War Damage Act}

New Zealanders are fortunate to have the protection of the benefits provided by the Earthquake and War Damage Act 1944. To qualify for such protection, the person is required to have a current contract of insurance with a direct insurer transacting business in New Zealand and one of the insured events must include loss or damage by fire. The maximum amount payable is limited to the sum insured or "indemnity value at time of loss, whichever is the lesser sum. For this protection the policyholder pays a premium of 5 cents for each $\$ 100$ of cover. This is collected by the direct insurer on behalf of the Earthquake and War Damage Commission, certain property is excluded from the cover provided by the Act, and if policyholders require insurance protection for such excluded items they should endeavour to insure these with the commission or a direct insurer.

\section{"Indemnity Value"}

Indemnity has many definitions, one being the depreciated value of property at the time of loss. If policyholders require protection against the risk of earthquake up to the replacement or reinstatement value of property they are required to insure for the "excess of indemnity" with direct insurers. The relevant policy wording should take careful cognisance of the Act and "dove-tail" into it.

\section{"Excess of Indemnity"}

As the gap between indemnity (or depreciated value or market value), and replacement or reinstatement cost increases, exacerbated by inflationary trends, then the demand for this additional cover or "excess of indemnity" increases the exposure of insurance companies to the consequences of a major earthquake.

\section{Exposure to Catastrophe}

This increasing exposure is a very real problem and is the subject of a special earthquake project undertaken by the United States National Committee on Property Insurance in the area of catastrophe management planning. I quote from their letter dated 4 November 1987 addressed to the commissioner of Insurance of California:-

"Experts are forecasting the financial devastation of the Property-Casualty Insurance Industry in the event of a major earthquake. When and where, in the United States the catastrophic earthquake will strike is not known, but it is a certainty it will happen. The potential exists that the insured damage may equal or exceed US $\$ 60$ billion. Can financial ruination be avoided? If so, how?" 


\section{Valuation Certificates}

Direct insurers in New Zealand invariably require valuation certificates to be completed by valuers, quantity surveyors, engineers, or architects approved by the Earthquake and war Damage Commission for the insurance of buildings, machinery and plant against the risk of earthquake. The format of this certificate has been agreed with the Commission and completion of such forms are mandatory where the insurer wishes to carry the risk of "excess of indemnity". The completed valuations have to be approved by the Commission so that the levy as prescribed by the Act can be calculated on the indemnity sum shown in the valuation. The Insurer strikes a rate on the amount insured in excess of indemnity to establish a premium for the risk carried by them, known in the market as "Company Earthquake". An alternative is the insuring of the earthquake risk offshore but then the whole risk including indemnity would then be carried by the offshore insurer.

Presumably most members of the Institution of Professional Engineers are familiar with this certificate, its content and related procedure (see Appendix 1). Suffice to say that the figures required by the certificate include indemnity value, reinstatement estimate, (including additional costs as necessary to comply with any Act of Parliament or with by-laws of any Local Authority), estimated amount required to cover the cost of any demolition or shoring up of the building, inflationary provisions of the indemnity value anticipated during the period of insurance, and the estimated amount of inflation and reinstatement costs anticipated during both the period of insurance and the estimated reinstatement period. The certificate then is a very useful point of reference when setting limits of liability under the relevant insurance policy although the bases of settlement can differ from one policy to another. These invariably give the insurer the option to reimburse, repair, or reinstate. If the insured person elects not to rebuild where the property is damaged beyond repair, then the wording of the policy may see the basis of settlement revert to indemnity value. Occasionally there may be provision for reinstatement on another site or other form of "portability". It is important therefore to examine the special insurance wordings for earthquake damage as these can vary considerably within the insurance market.

I referred in the preceding paragraph to the additional costs necessary to comply with Local Authority requirements and I can sympathise with valuers and engineers when allowing for reinstatement to current codes particularly if completing a certificate for large buildings built in the 1960's, some of which I understand would require significant strengthening.

\section{Claim Procedures}

Before a claim can be considered by the Commission, the insurer must provide a certificate of currency on behalf of the insured to the commission. This can become a logistic problem in the event of a serious earthquake when many claims are made. No major problems were encountered by either insurers or the commission following the Edgecumbe earthquake.

The Insurance Council, of which most insurers are members, has an Insurance Emergency Service Plan which is operable in the event of major catastrophes such as an earthquake but insurers still reserve the right to "go it alone" rather than be involved in a pooling of claims. The majority of insurance loss adjusters are independent contractors many of whom are experienced in handling disaster claims and are already "on call" to the commission. Thus the assessing and adjusting resource has to be shared between the commission and insurers in the event of earthquake. The practical solution is to agree dual appointments of such adjusters on property losses by insurers and the commission recognising that there is the potential for a conflict of interest. This proved successful in every case except one following the Edgecumbe earthquake.

The Insurance Council emergency plan has operated successfully in recent times in the Thames, Coromandel and South Canterbury floods but it did not operate in the Southland floods of 1984; nor was it considered necessary for it to operate in the Edgecumbe earthquake, the majority of claims being made initially against the Commission. However all these disasters have highlighted the need for close coordination between the commission, adjusters and insurers.

Whilst insurers may appoint valuers, quantity surveyors, engineers, architects, and other consultants to assist in the administering of a claim invariably it is the loss adjuster who appoints such specialists who in turn report to the loss adjuster.

THE ASSESSMENT AND UNDERWRITING OF THE EARTHQUAKE RISK TO PROPERTY, BOTH RESIDENTIAL AND COMMERCIAI

Until the demise of the Underwriters tariff in New Zealand 17 years ago, earthquake insurance was granted subject to rates, terms and conditions which were prescribed by the then Insurance Association, ie. a standardised approach was the norm. The rates built into the premiums were based on types of construction, eg. reinforced concrete or other, height of building, age (prior to 1940, 1940-1965, and after 1965) (see Appendix 2). The earthquake hazard was classified depending on whether the ground had been reclaimed or filled, whether foundations were set entirely in consolidated firm natural ground, or "least hazardous" where all foundations were set in hardbed rock. The rates then varied between $.125 \%$ and $.2 \%$ for dwellings and farm buildings; and between . $1 \%$ and . $5 \%$ for commercial buildings.

About 1978 the New Zealand insurance market became very soft. Currently rates for earthquake insurance vary between . $1 \%$ and 
$.125 \%$ for commercial industrial risks whilst some of the larger ones may be rated as low as $.07 \%$. It is difficult to be specific regarding rates for retail and residential earthquake risks as generally these have been packaged to the detriment of sophisticated underwriting. No longer is a premium necessarily built up by separate rates based on the risks of fire, extraneous risks (such as wind, storm and flood), earthquake, burglary, breakage of glass etc, but tends to be based on an overall competitive rate.

Few insurers in New Zealand use earthquake survey reports to assess the seismic risk. However at least one company calls for detail on the structure, structural condition, height, pre-existing damage, whether walls are braced on not, and the condition of the foundations. A numerical rating scale is used in conjunction with the report to enable a justifiable rate to be struck.

The majority of New Zealand insurers appear to assume that the estimated loss per building as a result of an earthquake will be $100 \%$ of the sum insured in the absence of specialised information. This can only result in insurers considering their accumulation of earthquake risk on a very pessimistic basis. There is a need then for a more scientific approach not only in the selection, assessment, and rating of risks but also in assessing the estimated probable maximum loss following an earthquake. Such an improved practice may enable insurers to carry more of the earthquake risk than they do at present. Since the damage to particular buildings from earthquake varies according to building characteristics, it seems evident that insurers require professional advice on structural and earthquake engineering to enable them to improve the selection and assessment of such risks.

SOME LESSONS LEARNT BY DIRECT INSURERS IN THE EDGECUMBE AND MEXICO EARTHQUAKES

The Edgecumbe earthquake brought home to many insurers that even a moderate earthquake such as 6.25 on the Richter scale can result in extensive property damage depending on the shallowness and focus of the epicentre and the intensity of ground shaking. Whilst that earthquake occurred in a thinly populated area there was a considerable degree of damage to domestic buildings involving some 6,000 claimants and 11,000 claims, several large commercial claims involving significant material damage and business interruption losses, and many uninsured losses. Much of the cost of the commercial and industrial claims is carried by reinsurance as the risk is spread by underwriters amongst professional reinsurers both in New Zealand and off-shore. Thus the cost effects of the Edgecumbe earthquake were felt as far away as New York, Geneva, zurich, Munich, Copenhagen, London and Melbourne. The earthquake brought home to several insurers the need to closely examine policy wordings particularly those submitted by brokers on behalf of their clients where they were seeking a non- standard wording to meet special requirements. It has emphasised the importance of having valuations of buildings and plant completed by specialists best qualified for that particular industry. It may be more practical to have qualified valuers estimate the indemnity value and to ask quantity surveyors and engineers to determine the estimated replacement cost. This may result in fuller insurance for our experience clearly indicates that actual reinstatement costs usually exceed those estimated at the time of effecting insurance even where due recognition has been made for escalation of costs during the insurance and rebuilding periods.

Then we were confronted by the so called Edgecumbe factor where certain builders and tradespeople faced with a heavy demand for their services, frequently loaded their hourly rates, often without justification.

As the bulk of the Edgecumbe claims were handled by the Earthquake and War Damage commission, insurance companies were not put to the test of meeting tens if not hundreds of thousands of claims which they could be faced with should a more serious earthquake strike a heavily populated area such as Wellington.

The Mexico earthquake did not produce many lessons for New Zealand insurers as Mexico City is a special case with a sophisticated method of underwriting the seismic risk there (see Apendix 3). Unfortunately few of the insurance clientele in Mexico could afford to pay the additional premiums required to extend their fire policies to cover the earthquake risk. Total number of claims received by the Mexican insurers equated to those received by both the commission and New Zealand insurers following the Edgecumbe earthquake. The many damaged and derelect buildings still standing in Mexico City are stark reminders that many of the owners were uninsured, or were insured and accepted cash settlements particularly as interest rates in the latter part of 1985 in Mexico were higher than the rate of inflation which certainly accelerated because of the earthquake. Furthermore there was no insurance cover provided for the cost of demolition and very little business interruption insurance was effected. The cost of those buildings still awaiting demolition will fall upon the state.

In New Zealand the Earthquake and War Damage Act does not provide for the cost of demolition. It is essential that insurers prevail upon their clientele, when requesting insurance protection in excess of the Act cover, to include the cost of demolition. Such costs vary considerably in the certificates of valuation. There is no differentiation of demolition costs whether as a result of fire or earthquake yet the costs of demolishing buildings and removing rubble are likely to escalate rapidly following a major earthquake and special consideration should be given when completing such certificates otherwise the insurance protection would be rapidly eroded. Picture the situation in Wellington with its concrete canyons, 
narrow streets, limited access, and sparce demolition services. I feel sure that a "Wellington factor" would rapidly become apparent!

In fairness to the commission, the insurers, reinsurers and loss adjusters, Edgecumbe earthquake claim payments were made promptly and apparently fairly. I have heard of no complaints to date from people who had adequate insurance protection.

The continuing lesson to be learnt by the public whether they be in New Zealand, Mexico or California, is that it is their choice to insure against the earthquake risk. Whilst the majority of New Zealanders are so insured, because of the way in which the Earthquake and War Damage Act is currently structured, a significant number of claimants still find themselves under-insured. Whilst most agree that california is more earthquake prone than New Zealand it is indicative to read that following the moderate size earthquake which occurred in Los Angeles in october 1987 and measured 5.9 on the Richter scale, there were 8,400 insurance claims which occurred with losses approaching US\$73 million yet insurable property damage was damaged to the extent of US\$358 million.

Earlier in this paper I referred to the earthquake project currently being undertaken by the US Insurance industry which not surprisingly has decided to concentrate on California and the exposure there to the seismic risk. Currently about $20 \%$ of residential structures are insured there against shaking damage and this incorporates a degree of adverse selection by the insuring population. Surprisingly only some $28 \%$ of commercial structures and contents are insured against ground shaking. It does seem that people everywhere have to be encouraged if not directed to protect themselves and their property whether it be from the risks of fire, earthquake, burglary, liability, or to adequately provide for superannuation. The problem, particularly in california, is that if everyone was to effect earthquake insurance there would be inadequate reinsurance to meet the demand. Some U.S. insurance companies say they would be seriously threatened without some involvement by the Federal Government. None of the figures referred to include losses from ensuing fires or business interruption or loss of rentals where incurred losses could easily absorb the sum insured.

\section{RECOMMENDATIONS}

1. Insurers must take the initiative and deal proactively with the problem of the seismic risk and the exposure thereof to their policyholders and shareholders. This problem could explode overnight. Recently the New Zealand media reported that Treasury were reviewing the future of the Earthquake and War Damage Commission and the contingent liability imposed on the consolidated account by the Act. No doubt the Earthquake and War Damage fund, currently standing at around NZ\$l.6 billion also has its attractions, particularly to a Government embarked on a programme of privatisation. This in itself, should assist in reducing that contingent liability as state owned enterprises arrange for the insurance of their assets.

It is rather ironic that a 1 iberal society such as California is currently debating the need for some Federal protection against the earthquake risk whilst here in New Zealand with its comparatively tiny population there are discussions afoot to terminate or progressively diminish the protection afforded to the insuring public of New zealand for the past 40 years.

2. Insurers must manage the seismic risk (and that of fire following earthquake) by identifying building earthquake risk factors and their contents and business interruption risks preferably commencing with risk surveys. Whilst this in the main would have to be done initially by insurance company surveyors there should be scope for professional engineers to operate a bureau for such surveying, assessing not only the risk but also the damage following the earthquake.

3. Once the stock of buildings has been so surveyed, the risks must be scientifically assessed and either accepted or declined. The pricing of accepted risks must be based on a sophisticated scale which takes the actual seismic risk into account as it does in all other earthquake prone communities and not be left to the vagaries of an over competitive market. Risk sharing with the insured could be developed further by applying "deductibles" from losses incurred.

4. As insurers are wholly dependent on world reinsurers for protection in case of catastrophe such as a major earthquake it would be prudent to adopt a common methodology such as that propounded by G.R. Birss [1].

5. A building by building approach would then enable insurers to assess their aggregated maximum probable losses and thus greatly assist in negotiating reinsurance requirements. Internationally much work has already been done in the control, supervision and underwriting of the earthquake peril by a technical study group of international insurers and reinsurers under the name of CRESTA which stands for Catastrophe Risk Evaluating and Standardising Target Accumulations, the secretariat being run by Swiss Reinsurance company in zurich. In my research for this paper, I came across the name of Bruno porro who is a member of the seismological society of America, the Earthquake Engineering Research Institute, and the New Zealand Society for Earthquake Engineering. He is leading the Catastrophe and Research Department of Swiss Re and I commend to you his article [2], particularly his comments on the price of earthquake cover. 
6. Insurers here must also give more attention to the risk of fire following earthquake as our building stock contains many wooden buildings (as it does in San Francisco) whilst most modern buildings contain highly inflammable contents. We cannot rely on a continuation of fire protection following an earthquake for many water mains would be fractured, streets would be blocked. With debris, and pressure could be lost thereby rendering many sprinkler systems ineffective.

The U.S. All-Industry Research Advisory council, based in Illinois, released last year a report entitled "Fire. Following Earthquake" (estimates of the conflagration risk to insured property in greater Los Angeles and San Francisco) prepared by Dr. Charles Scawthorn. This is most comprehensive and I conclude from it that if the 1906 San Francisco earthquake occurred today that city would still be faced with a most serious conflagration risk, the cost of which could exceed the shake damage, somewhere between US\$4 to US\$15 billion in the San Francisco Bay area depending on wind conditions.

Dr. Scawthorn considers that the methodology as presented in his report is directly applicable and useable by insurance companies. Whilst obviously he is referring to American insurers I am sure much can be gleaned by us in New Zealand from the report which could assist us in determining our exposure to the risk of fire following earthquake. Again this aspect and that of the business interruption risk or consequential loss, can be included in the proposed building survey questionnaire.

7. We at commercial Union in conjunction with a team of civil engineering advisers, have designed such a survey form so that a body of information can be obtained to evaluate a building's relative seismic risk. We readily appreciate that a more detailed assessment of the seismic risk would require the skills of a professional engineer. However such a form will assist us to build a database and from this we will re-assess our maximum probable loss and exposure to claims. It would be prudent to fully computerise such a database so that our exposure can be updated and reviewed regularly.

8. Not only insurers, but all parties likely to be involved in a major earthquake including loss adjusters, valuers, quantity surveyors, engineers, architects, builders, demolition contractors, should establish closer relationships with civil Defence and Local Authorities to improve disaster planning. Such parties should be represented through their National Associations on any National Committee for Disaster Planning or Civil Defence. Perhaps professional engineers could consider embarking on scenario planning in consultation with the appropriate bodies with a view to advising a committee such as the one set up in Mexico in 1985 for reconstruction and recovery. There, considerable pressure was placed on engineers not to write-off buildings as was their first inclination but to seek ways and means of saving as much of the damaged property as possible.

\section{CONCLUDING REMARKS}

one thing is clear, there will be a considerable shortage of resources in most areas and we would require considerable assistance from overseas. Full insurance either by way of the Earthquake and War Damage Act and/or by direct insurers, supported by worldwide reinsurers, will certainly not provide the answer to such devastation. It will only provide some of the funds necessary to reconstruct. As we know it is not a matter of "if" but "when" and it is encumbent upon us all Government, business people, and property owners - to seriously plan to manage such a disaster.

\section{ACKNOWLEDGEMENT}

The author is indebted to MunichRE NZ services Ltd for the extract from their publication entitled "Earthquake Mexico ' 85 " that is included as Appendix 3.

\section{REFERENCES}

1. Birss, G.R., "Methodology for the Assessment of the Damage Cost Resulting from a Large Earthquake in the vicinity of Wellington", NZNSEE Bulletin, vol. 18, no. 3, september 1985 .

2. Porro, B., "Earthquake Assessment What Can We Do", Journal of the Insurance Institute of New Zealand, September 1986 
APPENDIX 1

VALUATION FOR INSURANCE PURPOSES

(BUILDING)

1. Name of Insured

2 Address of Euiloing to Je Insured

(including street number)

3. Type of Oeccipanoy

4. Erief Detzils of Constriction

5. Age of Euinding

A CEATIFICATE OF INDEMNITY VALUE

In compiiance with the requirements of the Earthquake and War Damage Ac: I hereby cariify that the "iNDEMNITY VALUE of the Insured Euilding is

(Important-before applying depreciation the Valuer should incluce all lees as deined overleat-Note 1)

Valuer's Signature

Qualification

Date

Name of Valuer and Firm

Name of Insurance Company

Policy No.

Feriod of Poiicy is from

to

B. REINSTATCMENT ESTIMATE (See Note 3 overleat)

The estimated csst of rebuilding the property at the level of costs applying at the inception of the cumrent pericd of insurance ignoring the inflationary factors which may operate subsequent thereto including the use of currently equivalent buiicing materials and techniques and such additional costs as necessary to comoly with any Act ot Parliament or any Regulation uncer or framed in pursuance of any such Acs or with By-Laws of any Municipal or Local Authority finclusive of all fees as deined overlest-iNote 1).

$s$

Note (i) If the reinstatement estimate is based ucon the use of different materials and/or additicnal services from thcsa exising, brielly describe them

Note (iii) Ey what amounts do the consideravions reieres to in Note (1) increase the fieinstatement Cos??

$$
S
$$

Ncte (iii) What amount of additional costs necsesary to comply with any Regulation or Ey-Lew recuirement has been inc!uded in the Reinstatement Estimate?

$S$

Note (iv) Are there any Regulations prayenting reinstetement wholly or in farn? II so give triei detzils -

\section{DEMOUTON}

What is the estimated amount requirej to cover the cest of any Demolition Shcring up or fropping of the tuildirig caminges c: destrcyed and the Removal of Debris inctuding Contents whether damaged or not 
D. INFLATONARY PROVISION

(1) Incemnity (as defined in $A$ above)

The estimatej amount of inilation in "Indemnity Value" anticipated curing the perịcd of insurance oniy is

$s$

(ii) P.einstatement (as derined in 8 above)

The estimated amount of inflation in costs anticioated during both the period of insurance and the estimated reinstaiement period taking into consideration time resuired for damaçe insfections, demolition, preparation of new preilminary proposals and their approval, preparation of working drawings and speciticetions, schedule of quantities, obtainir.g City Council approval tenders etc. is

$\mathrm{s}$

Estimates under $\mathrm{B}, \mathrm{C}$ and $\mathrm{D}$ are given without prejucice

Sigivature

DATE

Name of Valuer and Firm

4/ss

NOTES:

1. FEES

These are to include Architects'. Surveyors;' Consulting Enģineers: and other fees for estimates, plans, scecifications, quantites and tenders and supervision necessarily incurred in the reinstatement consequent on destuction of or damage to the property insured but not such fees for preparing any claim under the policy.

2 EARTHOUAKE AND WAR DAMAGE ACT

Under a Reinstatement Policy the Earthquake and War Damage Ac: provides a means whereby the Earticuake and War Damage premium may be charged on the certined indemnity value only which then becsmes the maximum liabiity of the Commission

In order to receive this concession the following procedure must be followed-

At the commencement of each period of Insurance a certificate staing the INDE:INTTY VALUE must be submitted to the Commission. This certinicate is to be furnished by a Valuer who must be a registered member of $N Z$ Institute of Arciritects a Valuer registered under the Valuers AC: 1948, an Engineer registered under the Engineers Registration Act 1924 or a Cuar.tity Surveyor registered under the Quantity Surveyors Ac: 1960.

\section{3. "aENSTATEMENT SHALL MEAN}

\section{SUILINES}

(a) Where destroyed the rebuilding of the property inciuding the use of cumently equivalent builcing materials anc tecitnicues and sucin acoitional cosis necessary to comply with any Ace of Parliament cr any fiesulations uncer or tianes in pursuance of any such Ace or with Ey-Laws of any Municipal or Lecal Authority.

(ㄷ) Where damaged, the restoration of the damaged porion of the froperty to a cenciticn suiestantially the same as jut no better or more extensive than its concition when new but inciucing such acciticnal cosis necessary to cemely withi any Ac: of Parliament or any Regulations uncer or tramed in pursuance of any such Ac: or with Ey-1 aws ci any suct: Ac: or with Ey-Laws of any Municipal or Local Authorizy.

\section{PEOPSATY OTHEE THAN EUILDINGS}

The restcration of the damaged property to a condition jostanially the same as but nci berter or more exiensive than its candition when ne'w or if destroyed its replacement by sir "iar prosery in a condition sticsiantially the same as but nct terte? than the condition of the insured property when new. 


\section{RATES}

Earthquake insurance may be granted at the following rates and subject to the terms and conditions as set out hereunder :-

\begin{tabular}{|c|c|c|c|c|}
\hline 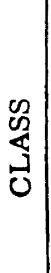 & $\begin{array}{l}\text { CONSTRUCTION OF BUILDINGS } \\
\text { Buildings and Contents }\end{array}$ & 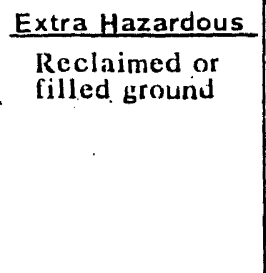 & $\begin{array}{l}\text { Hazardous } \\
\text { All foundations } \\
\text { set entirely in: } \\
\text { consolidatesf firm } \\
\text { 'natural grourfd }\end{array}$ & $\begin{array}{l}\text { Least Hazardous } \\
\text { All foundations set } \\
\text { entirely in hard bed- } \\
\text { rock or Granite and } \\
\text { certified to the } \\
\text { satisfaction of indiv- } \\
\text { idual Member } \\
\text { Companies }\end{array}$ \\
\hline 2. & $\begin{array}{l}\text { DWELLINGS \& FARM BUILDINGS of } \\
\text { any material not exceeding } 2 \text { storeys. } \\
\text { Buildings of one storey of any material } \\
\text { other than brick or concrete. } \\
\text { REINFORCED CONRETE Earthquake } \\
\text { resistant Buildings not exceeding } 6 \\
\text { storeys and constructed } \\
\text { (a) Prior to } 1940 \\
\text { (b) } 1940 \text { to } 1965 \\
\text { (c) after } 1965 \\
\text { REINFORCED CONCRETE Earthquake } \\
\text { resistant Buildings exceeding } 6 \text { storeys } \\
\text { and constructed } \\
\text { (a) prior to } 1940 \\
\text { (b) } 1940 \text { to } 1965 \\
\text { (c) after } 1965 \\
\text { Buildings not provided for under } 1,2,3 \text { or } 4 \\
\text { above and constructed } \\
\text { (a) prior to } 1940 \\
\text { (b) } 1940 \text { to } 1965 \\
\text { (c) After } 1965\end{array}$ & $\begin{array}{l}.400 \\
.375 \\
.325 \\
\\
.500 \\
.450 \\
.375\end{array}$ & $\begin{array}{l}.325 \\
.300 \\
.250 \\
.425 \\
.350 \\
.275\end{array}$ & $\begin{array}{l}.225 \\
.200 \\
.150 \\
\\
.275 \\
.225 \\
.175\end{array}$ \\
\hline
\end{tabular}

NOTES : -

1. Buildings comprising more than one of the above classifications to be charged the highest rate applicable.

2. No greater cover to be granted than the amount of Fire Insurance.

3. No commiss ion is payable on Earthquake Insurances.

4. Where Rent is insured the excess shall not apply to the Rent Item.

5. Where Earthquake (Fire and/or Shoch) is covered under a Loss of Profits Policy, the excess shall not apply under the Loss of Profits Insurance.

6. Where cover is granted under Regulations 46 or $46 \mathrm{~A}$ for Demolition or Removal of Debris the excess shall not apply.

7. Superstructures and Penthouses may be ignored in interpreting Number of Storeys.

8. It is recommended that the certification under the "Least Hazardous" class ification should ho given by a geologis $t$. 


\section{ENDORSEMENTS}

(a) (1) In consideration of the payment by the Insured of the sum of $\$ \ldots . . . . . . . . . . . . .$. additional premium, the Company agrees, notwithstanding what is stated in the printed conditiuns of this Policy to the contrary, that this insurance covers loss or damage by fire to any of the property insured by this Policy occasioned by or through or in consequence of carthquake and/or loss or damage to any of the property insured directly caused by earthquakc.

It is declared and agreed that in the event of loss or damage to the property insured directly caused by earthquake, this Company shall be liable to pay or contribute in respect of such loss or damage its proportion only of the amount by which such loss, or damage shall exceed $\$ 100$ during any period of 48 consecutive hours, but this condition? does not apply to loss or damage by firé caused by earthquake.

The $\$ 100$ above referred 10 shall apply to any one building or group of buildings or contents in the same ownership, located in one situation whether insured with one or more insurers.

It is further declared and agreed that in the event of loss or damage by fire occasioned by or through or in consequence of earthquake, or of loss or damage directly caused by carthquake, this Company shatl not be liable to pay or contribute in respect of such loss or dantage beyond the proportion which the sum insured against the risks covered by this endersement shall bear to the total insurance against ordinary. fire loss.

Provided further that this insurance shall be subject to the terms, provisions and conditions, other than Condition 17, of this Policy so far as they are applicable.

Same ats above, except that third paragraph be deleled and words "other than Condition

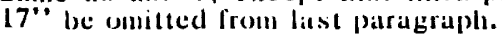




\section{Direct insurance and reinsurance of the earthquake risk in Mexico}

\section{Terms, conditions and rates}

Like the US and Canadian fire policies, the Mexican fire policy does not exclude earthquake, thus automatically covering the fire risk as a result of earthquake without applying any restrictions such as deductibles, etc.

The earthquake shock risk may be included in the policy by way of a supplement and payment of a premium loading. Consequential loss policies are subject to a market agreement specifying that earthquake shock coverage is granted only for fixed operating expenditure and not for the actual loss of profits.
Earthquake shock coverage is provided under the following uniform conditions throughout the Mexican market:

- Application of the full value principle (with underinsurance clause).

- Application fo a 25 per cent coinsurance borne by the policyholder (proportional share in losses).

- Application of a sum insured of 75 per cent of the regular sum insured in fire (an additional limit of liability being applied by the "coaseguro convenido" in a few cases).

- Application of a deductible of 2 per cent of the sum insured in earthquake ( $=1.5$ per cent of the sum insured in fire) without limitation of the maximum amount.
The Mexican earthquake tariff subdivides the country into 7 exposure zones:

Zone 0: low exposure

Zone 1: moderate exposure

Zone 2: high exposure

Zone 3: very high exposure

Zone T: transition zone (Mexico City only)

Zone C: soft sediments (Mexico City only)

Zone R: soft sediments (Acapulco only)
ANEXO CIRCULAR No. S-340

- ENDOSO DE tERREMOTO Y ERUPCION VOLCANICA

POLLZA DE INOENDIO CLAUSULA la-FIESGOS CUBIERTOS. - Lox bienes amparados por la poliza
a la cual se adhiere este endoso, quedom tambion cubiertos contra doño ma-
leriales causados directamento por Terremoto o por Erupcion Volcónica. a riales causados diroctamento por Terremoto o por Erupción Volcénica.

Si los bienes mencionados o parte de ollos fueren destruidor o dañados dentre de la vigencia del seguro consignada on la poliza, la Compañla onviene an Clésusula Cuaria del presente endoso y demb́s rolativas sin incluir el valor do mejoras (exigidas o no por autoridados) para dar mayor solidez al edilicio o edilicios alectados o para otros lines, en exceso de aquellar reparaciones necescria para repono
siniestro.

Los daños amparados por este endoso que acasione algún terremolo o enspción volotrica darán origen a una reclamacian separada por cada uno de esoa lehoras consecutivas durante le vigencia de aqubl. se lendrán como un solo sinies-

CLAUSULA 2a-BIENES EXCLUIDOS PERO OUE PUEDEN SER CUBIERTOS MEDIANTE CONVENIO EXPRESO. Salvo convenio expreso. esta Compañla no se

a) A albercas, bardas, patios exteriones, escaleras exteriores y cualesquiera otras construcciones separadas dol edificio o edificios o construcciones que expresto endoso.

CLAUSULA 3a.-BIENES Y RIESGOS EXCLUIDOS QUE NO PUEDEN SER CU.
GERTOS.-Esta Compañla on ningún ceso serd responsablo por deños a que este endoso at roliere:

a) A cimientos $y$ muras de contención debojo del nivol del pies mat bajo a muros do contención indepondientes $y$ a suelos $Y$ torreno.

b) A cualquier clase de Irescos o muralos que como motivo de decoración ticios o omanstrucciones aseguradas.

c) Causados directa o indirectamente. proximo o remotamente por reacciones nuclecres, radiaciones o contaminacionen radioactivas, ya soan controlad) Por marejada o inundación aunque talas lueren originadas por alguno
de los poligros contra los auales ampara este seguro.

ec.n.e s / $/$ einc.s $2 m-16 / \times 1 / 2$

221

$1 / m \mathbf{m}-\mathbf{n} \mathbf{n} / \mathbf{x} / \mathbf{m}$ e) Causados por vibraciones o movimientos naturales del subsuelo que sean
ajenos al terremolo, tales como hundimientos, desplazamientos y asentaaienos al terremolo, tales como
mientos normales no repentinos.

CLAUSULA 4a-CONTRIBUCION DEL ASEGURADO-Es condición básica para el otorgamiento de la cobertura establecida en este endoso que el asegurado brevenga a los bienes ategurados por terremolo o erupción volcánica. En caso de tener aplicación la Cláusula 4a. de las Condiciones Generales de la póliza, en virtud de que al ocurrir el siniestro los bienes osegurados tengan un valor su-

Dada la participación de pérdida a cargo del asegurado. la prima se calcularó en un $75 \%$ del valor declarado de los bienes asegurados contra incendio De existir otros seguros. Ia indemnización quedará limitada a la proporción que en el $75 \%$
seguros vigenles.

CLAUSULA 5a-DEDUCIBLE.-En cada reclamación por daños materiales o los editicios, consirucciones o contenidos amparados por esto endoso, se aplicaŕ un deducible del $2 \%$ sobre la suma asegurada de lemblor, la cual equivale al $75 \%$ del valor declarado para el seguro de incendio. Eslo de

Si el seguro comprende dos o más incisos o cubre bajo cualquier íneiso dos - mats edilicios, construcciones o sus conionidos. el deducible se aplicard separadamonle con roopocto a cada incto

CONDICIONES ESPECIALES PARA LA COBERTURA DE TERREMOTO O ERUPCION VOLCANICA OUE SE AGREGAN AL TEXTO DE ESPECIFICACTONES OUE FORMA PARTE DE LA POLUZA No.

\section{(PERDIDA DE UTHLIDADES)}

Es condición expresa do la poliza que, si la causa de la pérdida amparada por la misma en atribuible al riesgo de Terremoto o Erupcib́n Volénnica, operara en lodo caso, una participacion a cargo del asegurado de un $25 \%$ arbre el monto
total do la perdida y un deducible del $2 \%$ sobre la suma asegurada tijada do total do la perdida y un deducibliejel cubierto por la misma. Esto deducible se

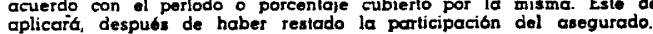

En caso de que el importe de las utilidades que sirvan de base para fijor la indemnización "sec superior al declarado, la indemnización se reducir
do con las "Clausulas Proporcionales" correspondientes.

Dada la participación de pordida a cargo del asegurado. la prima se calculara en un $75 \%$ del valor declarado para electos de seguro. De existir otros seguros, la indemnización quedara limitada a la proporción
que en ol $75 \%$ de la pordida corresponda a osta poliza on al total de seguros 
Zonas Expuestas a Terremoto, México

(Zonificación según la Tarifa Mexicana de Incendios)

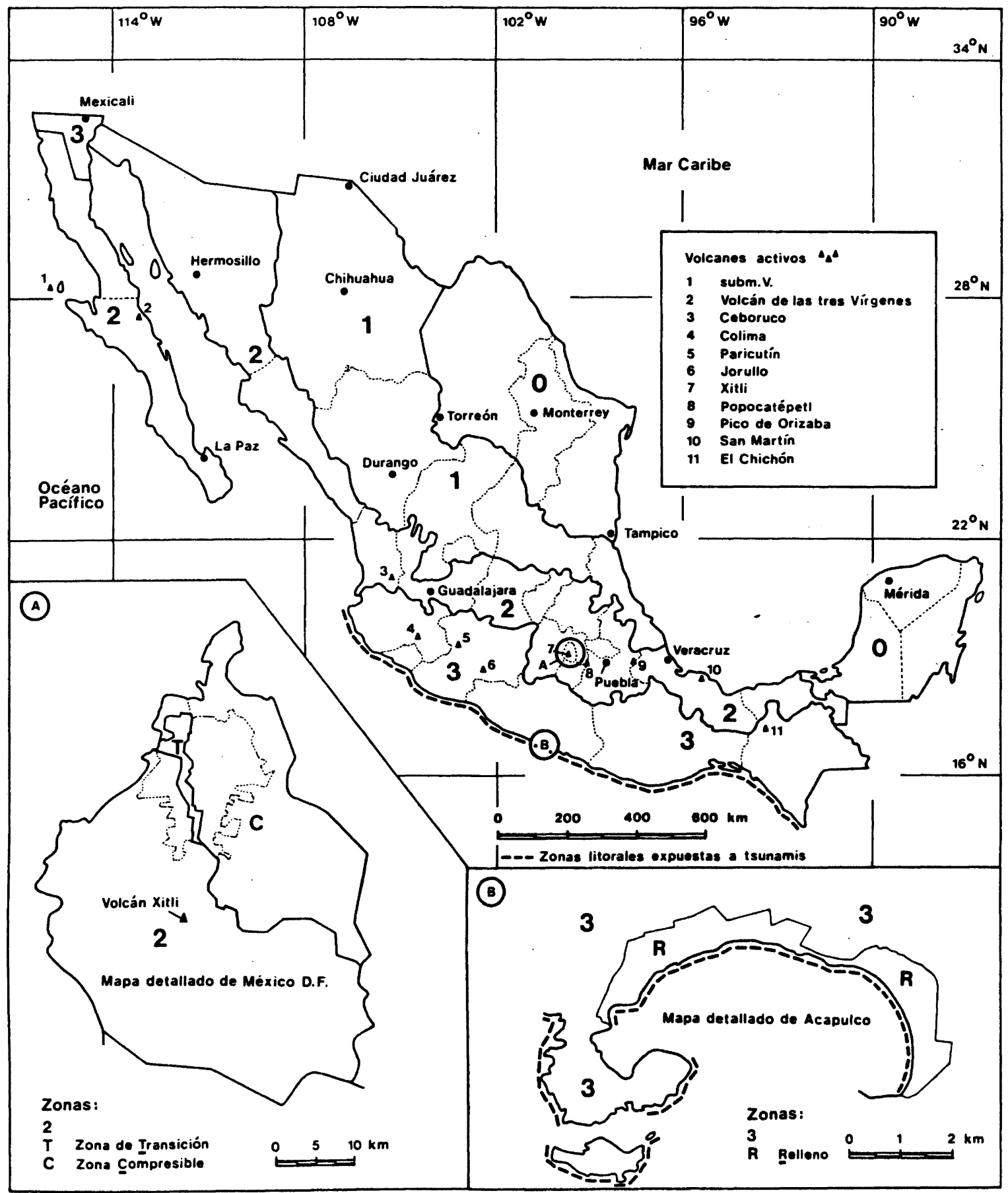




\begin{tabular}{|c|c|c|c|c|c|c|c|c|c|c|c|c|c|c|c|c|c|c|}
\hline \multirow{3}{*}{$\begin{array}{l}\text { Construc } \\
\text { tion class }\end{array}$} & & & & & & & & \multicolumn{11}{|c|}{ Multiplying factor applied to basic premium } \\
\hline & \multicolumn{7}{|c|}{ Basic premium in per mille } & \multirow{2}{*}{\multicolumn{3}{|c|}{ 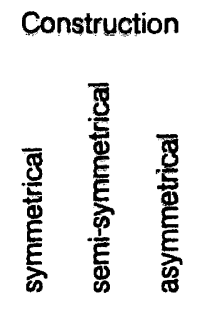 }} & \multicolumn{3}{|c|}{ Height } & \multicolumn{3}{|c|}{ Standard } & \multicolumn{2}{|l|}{ Design } \\
\hline & 0 & 1 & 2 & 3 & $T$ & C & $\mathbf{R}$ & & & & & & & & & & & \\
\hline 1 & 0.20 & 0.40 & 0.80 & 1.60 & 1.07 & 1.07 & 2.13 & 1 & 1.15 & 1.30 & 1 & 1.15 & 1.30 & 1 & 1.15 & 1.30 & 0.75 & 1 \\
\hline $\mid a, \|$ & 0.27 & 0.53 & 1.07 & 213 & 1.60 & 213 & 266 & 1 & 1.15 & 1.30 & 1 & 1.15 & 1.30 & 1 & 1.15 & 1.30 & 0.75 & 1 \\
\hline III, V & 0.27 & 0.53 & 1.07 & 2.13 & 213 & 2.13 & 266 & 1 & 1.15 & 1.30 & 1 & 1.15 & 1.30 & 1 & 1.15 & 1.30 & 0.75 & 1 \\
\hline$\| \mathrm{a}, \mathrm{IV}, \mathrm{V}$ & 0.33 & 0.67 & 1.33 & 2.66 & 2.66 & 2.66 & 266 & 1 & 1.15 & 1.30 & 1 & 1.15 & 1.30 & 1 & 1,15 & 1.30 & 0.75 & 1 \\
\hline $\mathrm{VII}$ & 0.20 & 0.40 & 0.80 & 1.60 & 1.60 & 2.13 & 213 & 1 & 1.15 & 1.30 & 1 & 1.15 & 1.30 & 1 & 1.15 & 1.30 & 0.75 & 1 \\
\hline VIII & 0.33 & 0.67 & 1.33 & 2.66 & 266 & 5.33 & 5.33 & 1 & 1.15 & 1.30 & 1 & 1.15 & 1,30 & 1 & 1.15 & 1.30 & 0.75 & 1 \\
\hline
\end{tabular}

The earthquake premium also depends on the type of construction, the number of floors and other criteria relevant to the risk

The tariff no longer provides for the application of "cuotas especificas", i.e. tariff deviations applied, for example, quite often in fire insurance.

It would appear absolutely essential to revise the current tariff, including the most recent experience. The tariff thus revised should specify - substantial - premium increases for sorne risk categories, in particular for high-rise buildings with a critical resonance frequency in zone $\mathrm{C}$ of Mexico City.

\section{Accumulation control}

Earthquake liability accumulations must be constantly monitored to allow a wellfounded assessment of the loss potential. After recognizing the vital importance of accumulation control years ago, Mexican insurers and their international reinsurers agreed that the Mexican Insurance Association AMIS should provide such control centrally for all companies in the market. So far covers have been subdivided by 18 accumulation assessment zones and, for each zone, by 44 types of risks depending. for example, on the type of construction and number of floors. A simplified accumulation control form is shown below. The liabilities shown must generally comply with the total liabilities in force at the date indicated and must not under any circumstances represent, say, the insurance covers written in the last 12 months. 